\title{
ケイ酸のゲル化による氷の濁りについて (II)*
}

\author{
$\mathrm{pH}$ および共存塩類とケイ酸のゲル化との関係
}

永 沢信 ${ }^{* *}$

著者1はさきに，製永用水に含まれるケイ酸が凍結に よってゲル化して氷に白色不透明の部分をつくり，この ゲルは水に溶けないために融解水のなかに固形物となっ て浮遊し，食用水あるいは冷菓の商品価値が著しく低下 すること，またこのような現象はある $\mathrm{pH}$ の範囲内でお きるらしいととを報告したが，引続き，ケイ酸液を用い て $\mathrm{pH}$ おび共存塩類とゲル化の関係,およびそれと関 連する 2〜3 の条件について検討したところ，ケイ酸の ゲル化の原因がある程度推論できるような結果が得られ たので以下に報告する。

\section{実 験 方 法}

\section{1. 製水方法}

製永中の理↔の条件が実験結果に影響を与えることが 考えられるので，実際の製水工場で試験をするのがもっ とものぞをしいのはもちろんであるが，製氷工場では実 呀操作上の障害が多いので，市販の低温保存箱を利用し て実験を行なった。すなわち，実験条件に合わせて調製 した試料水 $1 l$ を製永容器に入れ， $-20 \sim-23^{\circ} \mathrm{C}$ に調 節した低温保存箱のなかで製氷した。製氷容器は凍結に よる水の膨張に酎え，乙かも異物が溶出しないものであ る必要上，接ぎめなしのステンレススチール製容器を使 用したが，試料水の $\mathrm{pH}$ が低いときにはある程度の鉄の 溶出がみられた。たとえば $\mathrm{pH} 3$ の試料水を入れて室温 に 25 時間放置したところ，0.21〜0.24 ppm の鉄が検 出された。しかし，このように $\mathrm{pH}$ の低い試料水による 実験はそれほど件数が多くないのでそのまま実験を進め た。

ケイ酸の状態が時間的に変化することが知られている ので，試料水は実験開始直前に調製し，その一部を取っ て各成分を定量してから製氷を開始したが，調製してか ら製水開始までは短時間で，ヶイ酸の状態に変化がない
ことを数回の実験で確かめておいた。

所定の時間で製水したのち氷塊を取り出し， $25^{\circ} \mathrm{C}$ 以 下で融解し，融解水を定量用沪紙（東洋汇紙，No. $5 \mathrm{~A}$ ) で沪過し，汇紙は死化してケイ酸ゲルを重量法”で定量 した。沪液のケイ酸は重量法 (全ケイ酸)および比色

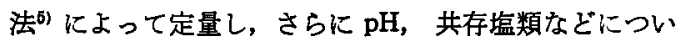
てむ測定した。

\section{2. 試料水の調製}

ケイ酸液は，化学用ケイ酸ナトリウム液（水ガラス） を溶解して調製した。 $\mathrm{pH}$ は塩酸, 硫酸またはケイ酸酸 性液を用いて調整したが，ヶイ酸ナトリウムを中和する ばあいは種々の条件によってケイ酸の状態が変動》する ことが知られているので，中和の条件はできるだけ一定 にするように注意した。

大部分の実験はケイ酸の濃度を $80 \mathrm{ppm} \mathrm{SiO}_{2}$ にして 行なったが，一般の饮料水として使われている天然水の ケイ酸濃度はほほこの範囲以内にあるという実用的な条 件を考虑して選んだ濃度である。共存塩類についての実 験では，普通に天然水に含まれている成分としてナトリ ウム,カルシウム，マグネシウムおよび鉄の，塩化物， 硫酸塩および重炭酸塩を選えだ。いずれす試薬 1 級品ま たはそれを原料として調製した塩類を用い，ほかの不純 物の混入を避けた。

塩濃度はいずれる水道水および飲料水の水質基準值を 参考にして、ナトリウム塩は $6 \mathrm{~m} M$, カルシウムおよ びマグネシウム塩は $3 \mathrm{mM}$ ，鉄は $0.3 \mathrm{ppmFe}$ とした。

3. 実験結果の表示について

ケイ酸濃度は $\mathrm{SiO}_{2}$ としての ppm で表わした。

融解水を沪過したときに，沪紙上に牫ったケイ酸ゲル の量を，試料水に含まれるケイ酸の総量に対する百分率 で示したものが「ゲル分率」である。

沪液には分子分散状（イオン状す含めてこう呼えでお

* 食品加工に扰ける用水の影帮とその対策（第 5 報）

** 東北大学農学部 (仙台市北 6 番丁 210)

On the Muddiness of Ice, Caused by Formation of Insoluble Silica-gel. (II).The effect of pH of water and its impurities. By Shin Nagasawa. 
第 1 表 告酸によって pH を調整したときの製氷によるケイ酸のゲル化

(ケイ酸漉度 $80 \mathrm{ppm} \mathrm{SiO}_{2}$, 慗水㭙間 25 時間)

\begin{tabular}{|c|c|c|c|c|c|c|c|c|c|c|c|c|}
\hline \multicolumn{5}{|c|}{ 試 料 水の $\mathrm{pH}$} & 3.0 & 4.0 & 4.5 & 5.0 & 5.5 & 7.0 & 8.5 & 10.0 \\
\hline 融 & 解 & 水 & の & $\mathrm{pH}$ & 3.0 & 4.0 & 4.4 & 4.9 & 5.4 & 6.9 & 7.0 & 8.3 \\
\hline ஜ゙ & $n$ & 分 & 率 & (\%) & 0 & 0.8 & 1 & 0.4 & 96 & 91 & 86 & 40 \\
\hline A & 型 & 分 & 率 & $(\%)$ & 97 & 88 & 85 & 84 & 4 & 8 & 11 & 57 \\
\hline B & 型 & 分 & 率 & $(\%)$ & 3 & 10 & 13 & 15 & 0.2 & 0.4 & 3 & 3 \\
\hline
\end{tabular}

注 $: \mathrm{pH}$ 啁整前のケイ酸ナトリウム液 $\left(80 \mathrm{ppm} \mathrm{SiO}_{2}\right) の \mathrm{pH} 10.3$

く）のケイ酸と，沪紙を通りぬけたコロイドケイ酸とが 混在すると思われる。後藤代はコロイドケイ酸が共存 するケイ酸液に比色分析用の発色削を加えたときに，直 ちに発色する部分をA型ヶイ酸，やや時間が経過してか ら発色する部分を B 型ヶイ酸と名うけて分類したが，A 型は主として分子分散状ケイ酸およびそれに近い数分子 以下が重台したケイ酸であり，B型はそれ以外の重合ヶ 洒帘であると考えられる。著者む沪液のケイ酸について A 型と B 型とを分別して，ケイ酸のゲル化の経過を知る 資料としたか＜wide>そそれらの量を試料水に含をれている全ヶ イ酸量に対する百分率で示したものを「A型分率」およ び「B型分率」とした。

\section{実 験 結 果}

\section{1. $\mathrm{pH}$ とゲル化との関係}

塩酸によって $\mathrm{pH}$ を調整して製水した結果は第 1 表の とおりである。

ゲル化は pH 5 付近まではきわめて少なく大部分のケ 洒が $\mathrm{A}$ 型であるが，それ以上の $\mathrm{pH}$ になるとゲル化が 著しくなり，pH 8くらいまではケイ酸の $90 \%$ または それ以上がゲル化する。 $\mathrm{pH} か ゙ 8.5$ 以上になれば再びゲ ル化の傾向がしだいに隇少するが， $\mathrm{pH} 10$ でも40\% は ゲル化する。もちらん，この傾向依，果して凍結しても ゲル化しにくいのか，それとも凍結によってゲル化はす るけれども融解の途中で再び浚解するために測定した時 点においてはA型になっていた，ということなのか㠜 問であるが，氷塊を製水容器から取り出した直後の肉眼 的な観察では， $\mathrm{pH}$ が低いときには水のなかの濁りもき わめて少なく，清澄な氷ができていたことからみて，や はり涷結によるゲル化そのものが少ないのであろう。

なお， $\mathrm{pH}$ が高くなると試料水と融解水とで $\mathrm{pH}$ の差 がかなり大きいが，この原因がなんであるかはよくわか らない。

以上のようなゲル化の傾向が，塩酸または塩素イオン によるものではないかを確かめるためにつぎの実験を行
第 2 表 硫酸およびケイ酸酸性液によって $\mathrm{pH}$ を調整 したとき，およびそれに Cl-を添加したもの の製氷によるゲル化 ケイ酸浱度 $80 \mathrm{ppm} \mathrm{SiO}_{2}$, 製办時間 25 時間,
試料水の $\mathrm{pH}$ i 7.0

\begin{tabular}{|c|c|c|c|c|c|c|c|}
\hline \multicolumn{5}{|c|}{ 試料水の種類 } & (1) & (2) & (3) \\
\hline 硐 & 解 & 水 & の & $\mathrm{pH}$ & 6.5 & 6.9 & 6.6 \\
\hline ゲ & ル & 分 & 率 & $(\%)$ & 88 & 96 & 94 \\
\hline A & 型 & 分 & 率 & $(\%)$ & 10 & 4 & 6 \\
\hline B & 型 & 分 & 率 & (\%) & 1 & 0.8 & 0.8 \\
\hline
\end{tabular}

なった。(1) 硫酸によって pH を調整した試料水。(2) イ酸ナトリウム液を $\mathrm{H}^{+}$型の強酸性陽イオン交換樹脂に よって $\mathrm{Na}^{+} \rightarrow \mathrm{H}^{+}$の交換を行なってっくったヶイ酸酸 性液によって $\mathrm{pH}$ を調整した試料水。(3) 上記 (2)の試料 水に，塩酸で $\mathrm{pH}$ を調整したときに混入するのと同浱度 塩素イオンを添加（NaCl 使用）したむの。 これら (1)〜3)の実験の結果を第2 表に示す。 塩酸によってpHを調整したときと大差なく,ケイ酸の 90\% またはそれ以上がゲル化することが明らかである。 水道水および飲料水に許容される $\mathrm{pH}$ は 5.8 8.6 で あるが，ちようどその $\mathrm{pH}$ 範囲でもっとむよくゲル化が おきることになるから，実用上はかなりめんどうな問䢎 になる。

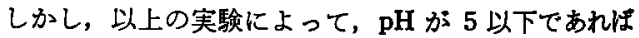
ケイ酸はほとんどゲル化しないことがわかったので，も しそうであれば有機酸によって $\mathrm{pH}$ を低くしている冷菓 などでは，ゲル化の心配がないはずであるが，弱㧎では 解離平衡が複雑で，低温になると $\mathrm{pH}$ が大きく变動する ことも考えられるので，種々の有機酸によって $\mathrm{pH} 5$ に調整したものを製水してみた。結果を第 3 表に示す。 この結果によると，有機酸によって $\mathrm{pH}$ を調整する と， $\mathrm{pH}$ が同じでもゲル化む， $\mathrm{A}$ 型と $\mathrm{B}$ 型の分革もかな り差があり，鉱酸によって $\mathrm{pH}$ を 5 亿調整したものと比 ベるとゲルやB 型が著しく多い。有機酸は解離度が小さ いが，低温になるために一㞒解䧸度が低下して，かなり 
第 3 表 有擲酸によって $\mathrm{pH}$ を調整したときの製氷によるケイ酸のゲル化

(ケイ酸浱度 $80 \mathrm{ppm} \mathrm{SiO}_{2}$, 製水時間 25 時間)

\begin{tabular}{|c|c|c|c|c|c|c|c|c|c|c|c|}
\hline 酸 & の & 種 & 類 & 塩酸 (対照) & 乳 & 酸 & 酢 & 酸 & クエン酸 & \multicolumn{2}{|c|}{ 酒石酸 } \\
\hline 䛋 & 料 & 水 0 & の $\mathrm{pH}$ & 5.0 & 4.9 & & 5. & & 5.0 & 5.0 & 4.0 \\
\hline 融 & 解 & 水 & の $\mathrm{pH}$ & 4.9 & 4.8 & & 4. & & 4.9 & 5.0 & 4.0 \\
\hline ゲ & ル & 分 & 事（\% & 0.6 & 8 & & 48 & & 67 & 90 & 52 \\
\hline A & 型 & 分 & 蚉 (\% & 35 & 48 & & 25 & & 19 & 3 & 30 \\
\hline B & 型 & 分 & 事* (\%) & 15 & 44 & & 27 & & 14 & 7 & 18 \\
\hline
\end{tabular}

第 4 表 塩化物が共存するときの彆氷によるケイ酸のゲル化

(ケイ酸濃度 $80 \mathrm{ppm} \mathrm{SiO}_{2}$, 製氷時間 25 時間)

\begin{tabular}{|c|c|c|c|c|c|c|c|c|c|c|c|}
\hline \multicolumn{5}{|c|}{ 塩の種 類と濃度 } & \multicolumn{2}{|c|}{$\mathrm{NaCl} 6 \mathrm{~m} M$} & \multicolumn{2}{|c|}{$\mathrm{CaCl}_{2} 3 \mathrm{~m} M$} & \multicolumn{2}{|c|}{$\mathrm{MgCl}_{2} 3 \mathrm{~m} M$} & \multirow{2}{*}{$\frac{\mathrm{FeCl}_{8} 0.3 \mathrm{ppm} \mathrm{F}}{7.0}$} \\
\hline 試 & 料 & 水 & の & $\mathrm{pH}$ & 7.0 & 8.5 & 7.0 & 8.5 & 7.0 & 8.5 & \\
\hline 融 & 解 & 水 & の & $\mathrm{pH}$ & 6.9 & 7.1 & 7.0 & 7.1 & 6.8 & 7.1 & 7.1 \\
\hline$\nvdash^{\circ}$ & ル & 分 & 索 & $(\%)$ & 79 & 75 & 77 & 67 & 77 & 73 & 89 \\
\hline A & 型 & 分 & 率 & $(\%)$ & 20 & 22 & 23 & 30 & 17 & 24 & 11 \\
\hline B & 型 & 分 & 率 & $(\%)$ & 0.8 & 0.4 & 1 & 2 & 5 & 2 & 0.1 \\
\hline
\end{tabular}

$\mathrm{pH}$ が高い条件で涷結することになってしまうためでは ないかと思かれるが， $0^{\circ} \mathrm{C}$ 以下の解離度がはっきりしな いし,また凍結の進行に伴う水中成分の濃縮との関係む 考えなければならないので, この点については目下検討 中であるが，実際的な問題としては，有機酸によって酸 味をつけた冷菓などでは $\mathrm{pH}$ がかなり低くとも，ケイ酸 がゲル化するおそれがあるということを知っておく必要 がある。

2. 塩類の共存とゲル化との関係

各種の塩類が共存したときのケイ酸のゲル化について の実呀結果は第 4 6 表のとおりである。なお，pHの 調整には, 塩化物のときは塩酸, 硫酸塩のときは硫酸, 重炭酸塩のときはケイ酸酸性液を用いた。

第 5 表 硫酸塩が共存するときの製为に上る ケイ酸のゲル化

(㢳酸浱度 $\left.80 \mathrm{ppm} \mathrm{SiO}_{2}\right)$

\begin{tabular}{|c|c|c|c|c|}
\hline $\begin{array}{l}\text { 㭚の㮔類と } \\
\text { 度 }\end{array}$ & $\begin{array}{c}\mathrm{Na}_{2} \mathrm{SO}_{4} \\
6 \mathrm{mM}\end{array}$ & $\begin{array}{l}\mathrm{CaSO}_{4} \\
3 \mathrm{~m} M\end{array}$ & $\underset{3 \mathrm{mM}}{\mathrm{MgSO}_{4}}$ & $\begin{array}{c}\mathrm{Fe}_{2}\left(\mathrm{SO}_{4}\right)_{8} \\
0.3 \\
\text { ppm Fe }\end{array}$ \\
\hline 試料水の $\mathrm{pH}$ & 7.0 & 7.0 & 7.0 & 7.0 \\
\hline 融解 水の $\mathrm{pH}$ & 6.4 & 6.7 & 6.4 & 6.5 \\
\hline ゲル分率 (\%) & 85 & 77 & 75 & 89 \\
\hline $\mathrm{A}$ 型分事 (\%) & 15 & 23 & 22 & 11 \\
\hline B 型分事 (\%) & 0.1 & 0.6 & 2 & 0.2 \\
\hline
\end{tabular}

ナトリウム，カルシウム，マダネシウムの塩化物，硫 酸塩，重炭酸塩のどれかが共存寸ればゲル化が少なく なった。

$\mathrm{pH}$ の変化は塩化物と硫酸塩とでは塩類がないぼあい と同様の傾向で, 凍結前と融解水とで活とんど変わりが ないかやや低下する傾向であるが，重炭酸塩では，融解 後のほうがやや上昇する傾向がみられた。これは倲結や 融解によって $\mathrm{HCO}_{3}{ }^{-}, \mathrm{CO}_{8}{ }^{2-}, \mathrm{CO}_{2}$ 相互の平衡がやや変 動するためであるうと思われる。

鉄塩が共存してもゲル化は添とんど変わらない。これ は鉄塩が微量なためと思かれるが，この量は水道水や飲 料水の許容限界であるから，その程度の鉄塩は裂水によ るケイ酸のゲル化には影響しないとみてよい。 つきに，以上のような塩類の影響を天然水について実

第 6 表 重炭酸塩が共存するときの製水による ケイ酸のゲル化

(ケイ酸漲度 $80 \mathrm{ppm} \mathrm{SiO}_{2}$ 製水時間 25 時間

\begin{tabular}{|c|c|c|c|}
\hline 塩の種類と濃度 & $\begin{array}{c}\mathrm{NaHCO}_{3} \\
6 \mathrm{mM}\end{array}$ & $\begin{array}{c}\mathrm{Ca}\left(\mathrm{HCO}_{3}\right)_{2} \\
3 \mathrm{mM}\end{array}$ & $\begin{array}{c}\mathrm{Mg}\left(\mathrm{HCO}_{3}\right)_{2} \\
3 \mathrm{mM}\end{array}$ \\
\hline 試料 水 の $\mathrm{pH}$ & 7.0 & 6.8 & 6.4 \\
\hline 融解水 の $\mathrm{pH}$ & 7.6 & 7.1 & 6.9 \\
\hline ゲル分率(\%) & 74 & 75 & 75 \\
\hline$A$ 型分事(\%) & 26 & 25 & 23 \\
\hline $\mathrm{B}$ 型 分革(\%) & 0.2 & 0.4 & 0.7 \\
\hline
\end{tabular}


第 7 表 天然水による䌘氷実験

(試料水は東北大学農学部樑井戸水)
慗水時間 25 時間

\begin{tabular}{|c|c|c|}
\hline 項 & 製办前 & 融解後 \\
\hline 蒸発残 留物 (ppm) & 286 & 一 \\
\hline $\mathrm{pH}$ & 7.9 & 8.0 \\
\hline $\mathrm{Mg}(\mathrm{ppm})$ & 1.2 & 1.1 \\
\hline $\mathrm{Ca}$ (ppm) & 18.7 & 10.8 \\
\hline $\mathrm{Fe}$ (ppm) & 0.04 & 0.00 \\
\hline \multicolumn{3}{|l|}{ ケイ酸 $\left(\mathrm{ppm} \mathrm{SiO}_{2}\right)$} \\
\hline$\ddot{ケ} \quad ル$ & 0.0 & 37.9 \\
\hline A 型 & 64.0 & 33.0 \\
\hline B 型 & 7.2 & 0.3 \\
\hline ケイ酸ゲル分率(\%) & 0 & 53 \\
\hline
\end{tabular}

第 8 表 製水による共存塩類の減少

（第 4〜6 表と同一条件）

\begin{tabular}{|c|c|c|c|c|}
\hline \multirow{2}{*}{$\begin{array}{l}\text { 陽イオン } \\
\text { の種 類 }\end{array}$} & \multicolumn{2}{|c|}{ 減 } & \multicolumn{2}{|c|}{ 宓 (\%) } \\
\hline & 塩化物 & 硫酸塩 & 重炭酸塩 & 天然水* \\
\hline $\mathrm{Na}$ & & 4 & 3 & - \\
\hline $\mathrm{Ca}(\mathrm{pH} 7.0)$ & 2 & 5 & 63 & \\
\hline (pH 8.5) & 15 & - & - & 51 \\
\hline $\mathrm{Mg}(\mathrm{pH} 7.0)$ & 0.4 & 2 & 6 & 8 \\
\hline$(\mathrm{pH} 8.5)$ & 0.1 & - & - & \\
\hline $\mathrm{Fe}$ & 93 & 100 & - & 100 \\
\hline
\end{tabular}

験した結果は第 7 表のとおりで，全体的にみればこれま での実験の結果とよく一致するとみてよいようである。

前報 ${ }^{1)}$ やこ第 7 表でわかるように，カルシウムや鉄 の濃度が製水によって減少するが，この点について実験 的に測定した結果を第 8 表に示す。

これでみると、ナトリウム, マグネシウムの濃度はほ とんど变化しないが，カルシウムの重炭酸塩が共存する ときはカルシウム浱度が著しく減少する。マグネシウム はアルカリ性の水のなかでケイ酸マグネシウムを形成し て沈殿する性質があり，天然水のケイ酸除去にも応用さ れているので， pH 8.5 ではそのような傾向がみられる かと思ったが，全く変化はなかった。

また，鉄はこの実験の程度の浱度では製水によってほ とえど完全に除去されていた。

3. その他の製水条件とゲル化との関係

（1）水塊中のゲルの分布

ゲルが生成した約 $1000 \mathrm{~cm}^{\mathrm{s}}$ の氷塊を上部と下部，中 央部と周辺部とに切り分けてから融解し，それぞれの部
分のゲルを定量したところ第 9 表のようであった。

これでみると中央部と下部に多いことがかかる。凍結 は周辺部から始まるから，周辺部はほとえど純粋な水に なり，水中成分は中央部に多くなるのは当然であるが， 下部に多いことからみると，周辺部が凍結して水中成分 がある程度濃縮されてくるとケイ酸は下部に沈降し，そ こでゲル化しながら封じこめられてしまうるのと考えら れる。

(2) ケイ酸の濃度について

ケイ酸の濃度を変えた実験の結果は第 10 表のようで あった。

ケイ酸濃度がかなり低くとも， $\mathrm{pH}$ 条件が同一であれ ぼ同程度にゲル化することがわかる。なお $30 \mathrm{ppm} \mathrm{SiO}$ というケイ酸はわが国の天然水にはかなり一般的に含有 されている量である。

（3）倲結しない程度に冷却したとき

凍結しない程度の低温 $\left(0^{\circ} \sim-1^{\circ} \mathrm{C}\right)$ に 48 時間およ 第 9 表 氷塊中のゲル分布

(試料水のケイ酸浱度 $90 \mathrm{ppm} \mathrm{\textrm {SiO } _ { 2 }}$ ) 製水時間 25 時間

\begin{tabular}{|c|c|c|c|}
\hline \multicolumn{2}{|c|}{ 部分別 } & 融解水の体積分案 & ゲル分事 \\
\hline \multicolumn{2}{|c|}{ 上 } & 46 (\%容) & $15(\%)$ \\
\hline \multicolumn{2}{|c|}{ 下 } & 54 & 85 \\
\hline 中 & 央 & 35 & 91 \\
\hline 周 & 辺 & 65 & 9 \\
\hline
\end{tabular}

第 10 表 ケイ酸濃度とゲル化の関係

(製丞時間 25 時間,

試料水の $\mathrm{pH} 7.0$

\begin{tabular}{c|cccc}
\hline \hline $\begin{array}{c}\text { ケイ酸浱度 } \\
(\mathrm{ppm} \mathrm{SiO})\end{array}$ & 30 & 50 & 80 & 100 \\
\hline 融解水の $\mathrm{pH}$ & 6.9 & 6.8 & 6.9 & 6.7 \\
ゲル分率 (\%) & 94 & 93 & 95 & 96 \\
$\mathrm{~A}$ 型分事 (\%) & 5 & 7 & 4 & 3 \\
\hline
\end{tabular}

第 11 表 冷却したときのケイ酸の状態

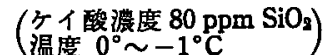

\begin{tabular}{c|cll}
\hline \hline 冷 却 時 間 & 0 時間 & 48 & 96 \\
\hline $\mathrm{pH}^{*}$ & 7.0 & 6.6 & 6.7. \\
ゲ ル 分率(\%) & 0 & 0 & 0 \\
$\mathrm{~A}$ 型 分率(\%) & 99 & 77 & 72 \\
$\mathrm{~B}$ 型 分率 $(\%)$ & 0.4 & $23^{* *}$ & $28^{* *}$ \\
\hline
\end{tabular}

注：・室温にもとして测定

** 計算值 
第 12 表 型氷時間とケイ酸のゲル化との関保

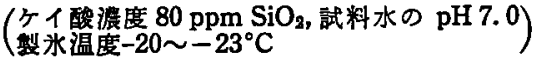

\begin{tabular}{|c|c|c|c|c|c|c|c|}
\hline $\begin{array}{l}\text { 梨 成 (時間) } \\
\text { 谏結部の 体樌分率 (\%容) }\end{array}$ & $\begin{array}{r}5 \\
16\end{array}$ & $\begin{array}{l}10 \\
49\end{array}$ & $\begin{array}{l}15 \\
75\end{array}$ & $\begin{array}{r}19 \\
100\end{array}$ & $\begin{array}{r}20 \\
100\end{array}$ & $\begin{array}{r}25 \\
100\end{array}$ & $\begin{array}{r}30 \\
100\end{array}$ \\
\hline 凍 結 部のゲル 分率（\%） & 0 & 0.6 & 2 & 65 & 91 & 90 & 91 \\
\hline " $\quad \mathrm{A}$ 型分率 $(\%)$ & 0.4 & 1 & 1 & 18 & 8 & 10 & 10 \\
\hline B 型分率 (\%) & 0 & 0.2 & 0.2 & 17 & 1 & 1 & 0 \\
\hline 末谏結部の ゙゙ル 分率 (\%) & 0 & 2 & 11 & - & - & - & - \\
\hline " $\quad \mathrm{A}$ 型分率 $(\%)$ & 100 & 96 & 72 & - & - & - & - \\
\hline B 型分虫 (\%) & 0 & 0.8 & 14 & - & - & - & - \\
\hline
\end{tabular}

び 96 時間冷却したときのケイ酸の状態は第 11 表のと おりであった。

冷却時間が長くなるとケイ酸の重合が進えで， B 型の 分率が增加するが，この実験の程度の時間ではゲル化と いうほどにはならない。るっと長時間冷却すれぼどうな るかわからないけれども，凍結されなければゲル化はそ れほど急速におきないことは確かめられた。

（4）整水時間比ついて

製办時間の長短とゲル化との関係注第 12 表のとおり であった。

これでみると，製水するときのような低温になると， 末凍結部にもある程度のゲルが 生成することがわかる が, その量はわずかであって, 結局は $\mathrm{A}$ 型 $\rightarrow \mathrm{B}$ 型に変化 したものが凍結によってゲル化するものが多いようであ る。東結がはじまれは温度は氷結温度で一定になるのは 当然であるが，周囲がかなり低温に保たれているから周 辺部は温度の低下が速く，あるいは過冷却のような状態 になっていて，そのなかで未凍結部でゲル化がおきるの

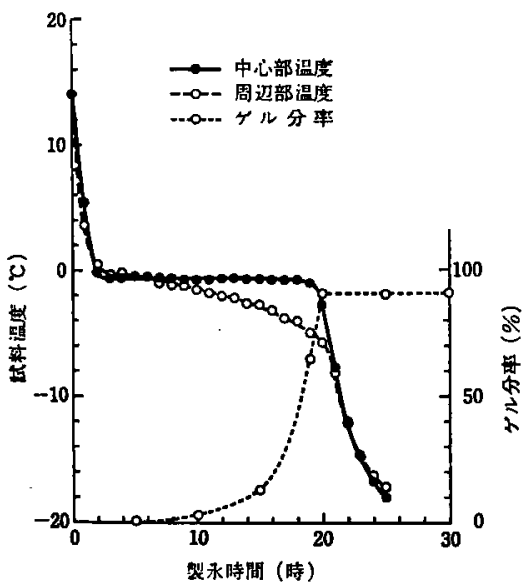

第 1 目 試料水の温度変化とゲル分虫の変化
ではないかとも考えられたので，製氷容器にサーミスタ 温度計を取りつけて温度变化を測定したところ, 第1図 のように中心部ではほとんど標準的な凍結温度曲線が得 られ，周辺部はやや温度低下が速いが，これは周辺部が 完全に凍結したためと思われるので，過冷却によって未 凍結部にゲル化がおきるということはないようである。

\section{結果の考察}

以上の実験結果を全体的にみるとつぎのようなことが

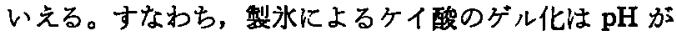
$5.5 \sim 8.5$ の範囲で製水するときにもっとも著しく，含 まれているケイ酸の $90 \%$ またはそれ以上がゲル化する。 それ以下の $\mathrm{pH}$ ではほとんどゲル化せす，それ以上の $\mathrm{pH}$ でるかなりゲル化が少なくなる傾向があって，また この傾向は $\mathrm{pH}$ を鉱酸で調整するかぎり，酸の種類やケ イ酸の濃度に無関係のようである。有機酸によって $\mathrm{pH}$ を調整したときには $\mathrm{pH}$ が 5 の試料水を使ってもかなり ゲル化が著しいものがある。この現象は，試料水が冷却 されて低温になるために酸の解離度が変化し，また凍結 によって水中成分が濃縮される影響むあるので，目下検 討中であるが，製水によるケイ酸のゲル化が水の $\mathrm{pH}$ と きわめて密接に関係していることは明らかである。

水中におけるケイ酸の状態と $\mathrm{pH}$ との関係については 後藤(1)ー6)そのほかの詳細な研究がある。

後藤は,ケイ酸ナトリウム液の $\mathrm{pH}$ を調整したときに

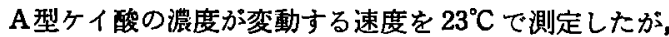
その結果， $\mathrm{pH}$ 2 3の範囲ではA型ケイ酸が多く，その 減少速度も遅いが， $\mathrm{pH}$ がそれ以上，とくに $\mathrm{pH}$ 6〜8で は $\mathrm{pH}$ を調整した直後であ大部分がB型であった。これ は，分子分散状である $\mathrm{A}$ 型ケイ酸が重合して B 型に变化 する速度が $\mathrm{pH}$ によって变わるためで，この重合の速度 は分子分散状ヶイ酸の濃度について 3 次反応であるか， 
さらにその反応速度定数が $\mathrm{OH}$ イオンの浱度に比例す ることを見ている。

また，後藤は分子分散状ケイ酸と重合ケイ酸との平衡 関俰について測定し， $0^{\circ} \mathrm{C}, \mathrm{pH}$ 5.5 8 の範囲では分子 分散状ケイ酸の平衡濃度(これを溶解度と考えてもよい) はほほ $100 \mathrm{ppm} \mathrm{SiO}_{2}$ で一定していて，pH がそれ以上 になると溶解度はかなり增加すること，溶解度は $100^{\circ} \mathrm{C}$ 以下では温度の低下とともにほほ直線的江減少するこ と，平衡に達するには 1 週間くらいかかること，などを 報告している。そうして，ケイ酸核溶解度までは分子分 散状で存在するが，それ以上の浱度になると重合をおこ し，分子分散状ヶイ酸と重合ケイ酸とが平衡を保ってい る。しかし， $\mathrm{pH} か ゙ 9$ 以上では溶解度がはなはだ大きい ために，よほどケイ酸が高浱度でなければ重合ケイ酸は できないしゲル化もおこらない，としている。

さらに，重合ケイ酸が分子分散状にもどる解重合につ

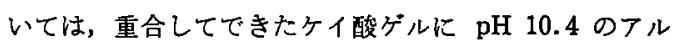
カリ液を加えると解重合がおきるが，その速度はケイ酸 が重合するときの条件によって差があり， $\mathrm{pH} 3.8$ 以下 で生成したものはきかあて速く，中性またはてルカリ性 で重合したものに比べて 100 倍も速いことを見ている。 ALEXANDER そ) 重合ケイ酸は生成するときの $\mathrm{pH}$ が 3.2 を境として重合の機構も生成物の性質も異なることを指 摘している。

以上のとおりであるから，著者の実験で， $\mathrm{pH} \mathrm{5.5〜}$ 8.0 の試料水でもっとも多くゲル化したことは，この $\mathrm{pH}$ 範囲内ではA型ヶイ酸 $\rightarrow$ B 型ケイ酸の重合がもっともす みゆかで，試料水が泠却されているあいだに大部分が $\mathrm{B}$ 型に変化し，それが湅結によって一部分脱水されてゲル 化したと考えると解釈できる。 $\mathrm{pH}$ が低いところで製水 すると $\mathrm{A}$ 型 $\rightarrow \mathrm{B}$ 型の変化が漣いために凍結してもゲル化 せず，また B 型になったるのも解重合が速いために融解 の途中でA型にもどてっしまうと思われる。

また，製办の途中で低温に長時間保たれるために溶解 度の平衡が $\mathrm{A}$ 型 $\rightarrow \mathrm{B}$ 型の方向へ移動し，また一部分が凍 結しはじめるとケイ酸が濃䌅されることになるために濃 度が上昇し，一層A型 $\rightarrow \mathrm{B}$ 型の变化を促進することも考 えられる。

つきに，B型ケイ酸がゲル化する機構については，凍 結による部分的な脱水であろうと考光られるが，これに ついて参考になるの水ガラスについての八喓屋と浮 楿》) の研究で，同氏ら汶，水ガラスは水中に㧅て Si-O の鎖状結合の側面に-ONa や OH 基を持っていて，これ らが強く水和して鎖状分子の結合をさまたげていること
を指摘している。ケイ酸が集合して重合ケイ酸になった ものが, 凍結によって一部の水和水が除去されて強固な ミセ儿構造に变化し，ゲル化すると考えられる。

塩類の共存によってケイ酸のゲル化が減少することに ついては，海水中ではケイ酸の重合が遅く，また解重合 がおきる傾向むあることを後藤们や岩崎高が報告してい る。したがって著者の実験のばあいもこれと同しょうな 理由によるものと思われるが，水道水や欲料水䍇容さ れる程度の塩類搌度では幾分ゲル化が少なくなるという 程度であって，実用的にゲル化の防止ができるほどのむ のではない。

カルシウム塩のうち，とくに重炭酸塩のぼあいには製 氷後の融解水にカルシウムが藷しく隇少したが，これは 前報1に述へたようにカルサイトになって共沈したもの とみられる。しかし，炭酸水素カルシウムの溶液を単独 で製水してみたところ，カルシウム浱度に变化がみられ なかったことからみて，この現象に対してケイ酸のゲル 化がなんらかの影響を与えているのかとも思われる。

鉄塩が製衤によってケイ酸ゲルと共沈することは，ゲ ルの着色からみても明らかであるが，これがゲル構造の なかへ包みこまれているのか,ゲル满造の一部人組みこ まれているのか忏不明で，今後検討する予定である。

要旨

前報に引き続き，ケイ酸を含む水を凍結したときに生 成するケイ酸ゲルについて,ケイ酸液を用いて実験し， その機構を推論した。

水中のケイ酸注 $\mathrm{pH} 4$ 以下では分子分散状であるもの

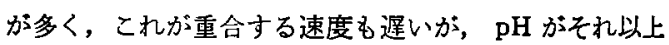
になると分子分散状のケイ酸は急速に重合ケイ酸に変化 することが知られていたが，著者の実験では $\mathrm{pH}$ 5.5 8.5 の試料水で製水したときにもっともよくゲル化し た。これは重合ケイ酸が谏結されてある程度脱水されて ミセルを形成し，ゲル状になるものと思われる。

共存塩類として $\mathrm{Na}, \mathrm{Ca}, \mathrm{Mg}$ の塩化物, 硫酸塩, 重

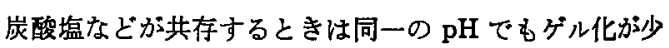
ないがこれも塩類の共存による重合傾向の減少によっ て説明することができる。

終りに，本研究に対し終始熱心に協力された山口健 設, 横倉実の両君に謝意を表する。また，オルガノ株式 会社の援助を受けたことを感謝する。

文献

1）永沢 信：食品工橲, 11，(6), 227(1964): 
2） -日本水道協会：上水試験方法， p. 200.(1960). - 半谷高久水: 質調查法, (丸善), p. 250 (1960).

5）後藤克巳：日化， 76，1364（1955）。

-高木誠司：定量分析の実験之計算，第 1 巻（共

6) 後藤克巳：日化，77,957 (1956).

立出版), p. 263 (1953), など.

3）・青木文雄：日化, 71, 634 (1950).

7) Alexander,G.B., Heston,W.M. and IleR, R.K.: J. Phys. Chem., 58, 453 (1954).

- 岩崎岩次：分析化学，9，184(1960)，など

4) - 後藤克巳: 日化, 76,729 (1955).

8）八幡屋正・浮橋 宽：化学々工業，5，288(1952).

9) 岩䗁岩次 - 橪谷俊和 - 桂敬 - 有野博文:日化, 75,857 (1953). 